\title{
Comparison and assessment of the setting zone choices by elite male and female volleyball setters in relation to opposing block organization
}

\author{
STAVROULA TSAVDAROGLOU ${ }^{1}$, KONSTANTINOS SOTIROPOULOS $^{2}$, KAROLINA BARZOUKA ${ }^{3}$ \\ ${ }_{1,2,3}$ School of Physical Education \& Sport Science, National and Kapodistrian University of Athens, GREECE
}

Published online: November 30, 2018

(Accepted for publication November 20, 2018)

DOI:10.7752/jpes.2018.s5325

\begin{abstract}
The purpose of this study was the comparison of the setting zone choices by male and female elite setters, as well as their resulting impact on the organization of the opponent block. A three-member group of experienced coaches assessed the actions of male (M) and female (F) setters and the blocking organization from 20 volleyball games $(\mathrm{M}=10, \mathrm{~F}=10)$ of National Teams competing in the final phase of World League 2017. The evaluated actions were $3904(\mathrm{M}=1811, \mathrm{~F}=2093)$. Intra-rater and inter-rater reliability coefficients were found to be $r=1.0$ and $r=1.0$, respectively, indicating very high consistency in the assessment procedure. The test of independence for the categorical variables (gender-setting zones, setting zones-block formation) was carried out using the Fishers exact test. Following the overall independence test we tested the difference in proportions between genders for each level of the "setting zone" and "block formation" variables using the statistical package Statgraphics Plus v. 5.1. Results showed that zone 4 was the first setting choice for both genders while men preferred the setting to zone 1 compared to women who preferred zone 2.Men with their tactics mainly released attackers from zones 6 and 3 while women released attackers from zone 2. Also, men confronted organized block when attacking from zones 1 and 4 while women when attacking from zones 2, 3, 4 and 6 . Therefore, coaches must consider the differences of the setting distribution strategy between genders since they affect the organization of the opponent block.

Key Words:volleyball, elite, setting, block, gender
\end{abstract}

\section{Introduction}

Volleyball is probably one of the most popular sports in the world (Reeser\& Bahr, 2003). Therefore, numerous studies have investigated players' performance with the aim to determine the factors that will result in improving the effectiveness of training and, consequently, competition. Among those factors, service reception has been found to affect the performance of the set, in terms of quality, the strategy of the setter and the effectiveness of the attack (McGown, 1974; Papadimitriou, Pashali, Sermaki,Mellas\&Papas, 2004; Barzouka, Nikolaidou, Malousaris, \& Bergeles, 2006; Zetou, Moustakidis, Tsigilis \& Komninakidou, 2007). In addition, several studies have found an association between reception effectiveness and its effects on the result of the match (Silva,Lacerda \& João, 2014). Another important factor that determines the next actions' efficacy and up to a certain level the final result of the game, is the setting (Buscà\&Febrer, 2012; Silva, Lacerda \& João, 2013; Palao, Santos \&Urena, 2005). Setting is an essential action in volleyball, not only from the technical point of view, but also from the tactical one, as it affects the attack, being the setter the specialist player who is responsible for organising the game (Buscà and Feber, 2012; Silva et al., 2013). It is not uncommon to hear the claim that he or she is 'the brain in the team'(Vujmilovic \& Karalic, 2013). The setter is the player that takes the majority of tactical decisions as he or she is responsible for deciding where the ball is to be passed. The setter has to evaluate the limitations encountered in agreement with the game context (Afonso, Mesquita, Marcelino \& Silva, 2010) seeking, with his or her action, to impair the attack-defence of the opposite team (Palao \& Martinez, 2013). The higher the performance of the setter, the higher the performance of the attackers in both genders (Bergeles, Barzouka \& Nikolaidou, 2009). Regardless of the previous action efficacy, high-level setters are able to achieve optimum sets from inappropriate preconditions (Papadimitriou et al., 2004; Palao Santos \&Urena, 2004, 2005; Zetou, Moustakidis, Tsigilis \& Komninakidou, 2006). This results in the setters being able to diversify the attack of their teams, producing a high variability of the setting action (Marcelino, Sampaio \& Mesquita, 2012). This variability causes the teams to be less predictable in attack (Marcelino, Afonso, Moraes \& Mesquita, 2014), destabilizing the opposing block (Mesquita \& Graça, 2002).

The block is the first line of defence that teams have in order to counteract the opponents' attack, as well as being a way to get the point directly (Mesquita \& César, 2007). In male volleyball, the block action differentiates the level of the teams (Palao et al., 2004). In general, if there is no effective blocking, the back row will not be able to play effectively (Wang \&Chen, 2017). However, the adequate decision-making of the setter in 
the setting action (setting zone, type of set, set's area and tempo of the set) could affect the block participation (González-Silva, Fernández-Echeverría, Claver, Conejero \& Moreno, 2017). He or she has to distribute the game bearing in mind the opposite team's block (Castro, Souza \& Mesquita, 2011), creating offensive situations that upset the balance of the block (Afonso et al., 2010). Indeed, one of the main purposes of the setter is to leave the attacker in the best conditions to attack, taking into account the opponent team. That is, to leave the attacker compete against the minor number of blockers (Moreno, Moreno, Ureña, Iglesias \& Del Villar, 2008) and to create uncertainty in the opponent team increasing the defence deficit of time (Fröhner\& Zimmermann, 1996; Palao et al., 2005).

As in other sports, differences also occur in volleyball depending on whether the players are male or female. Their competitions are governed by the same rules and regulations, with the only exception being the height of the net. More specifically, in women's competitions the height of the net is at $2.24 \mathrm{~m}$ while in men's competitions is at $2.43 \mathrm{~m}(\mathrm{FIVB}, 2018)$. However, it has been shown that in equally-trained men and women, women's upper and lower body absolute muscular strength corresponded to $55 \%$ and $72 \%$ of men's strength, respectively (Bishop, Cureton \& Collins, 1987). In addition to this, the male volleyball players of the USA national team were found to be taller and have higher upper body strength as well as jumping performance than female players (Carter, Powell-Santi \& Rodriguez Alonso, 1994). These distinguishing differences between genders have been found to be relevant to some performance differentiations between male and female volleyball players. For example, in terms of game complexes, the number of moves carried out in KII is greater in the female gender than in the male (Bergeles et al., 2009; Costa,Afonso, Brant \& Mesquita, 2012). Moreover, the use of the techniques and their efficacy has been found to be different for males and females (Palao, Manzanares \& Ortega, 2009). Taking into consideration the above it would be logical to hypothesize that the relation between the setting zone choices of elite men and women setters and the structure of the opponent's block might be quite different.In any case, the decryption of the setting distribution choices in high level volleyball, as well as its consequences to the block formation of the opponent team would be a useful tool for the coaches to improve both the effectiveness of training and competition. The purpose of this study was the comparison of the setting zone choices by male and female elite setters, as well as their resulting impact on the organization of the opponent block.

\section{Materials and Methods \\ Procedure}

A three-member group of experienced coaches assessed the setting zones choices of male and female setters and their consequent opponent block formationfrom 20 volleyball games $(\mathrm{M}=10, \mathrm{~F}=10)$ of National Teams competing in the final phase of World League 2017.Firstly, the coaches were asked to observe and categorize the setting choices according to the consequent attacking area i.e. to the zones 1, 2, 3, 4, 5 and 6 and secondly, the formation of the opponent block derived from the preceding setting distribution choices i.e. no block or single block or double or eventriple block formation. The evaluated setting actions were $3904(\mathrm{M}=$ $1811, \mathrm{~F}=2093)$ while the evaluated blocking actions were $3879(\mathrm{M}=1804, \mathrm{~F}=2075)$. Intra-rater and inter-rater reliability coefficients were found to be $r=1.0$ and $r=1.0$, respectively, indicating very high consistency in the assessment procedure.

\section{Statistical Analysis}

The test of independence for the categorical variables (gender-setting zones and setting zones-block formation) was carried out using the Fishers exact test (implemented with the statistical package SPSS v. 17). Following the overall independence test we tested the difference in proportions between men and women for each level of the "setting zone" and "block formation" variables using the statistical package Statgraphics Plus v. 5.1 .

\section{Results}

Setting zone choices by male setters

Male setters carried out 1811 setting actions, in total. Of these, 13.1\% were sent to zone $1,18.3 \%$ to zone $2,20.2 \%$ to zone $3,39.5 \%$ to zone $4,0.1 \%$ to zone 5 and $8.7 \%$ were sent to zone 6 . The comparison of percentages and frequencies showed that men set the ball more frequently to zone 4 in comparison with the zones $1,2,3$ and $6(z=-7.51, p=0.00, z=-6.80 p=0.00, z=-6.39 p=0.00$ and $z=-10.82, p=0.00$, respectively). Moreover, men set the ball more frequently to zone 3 in comparison with the zones 1 and $6(z=-2.25, p=0.02$, and $\mathrm{z}=-14.30, \mathrm{p}=0.00$, respectively), to zone 2 in comparison with the zone $6(\mathrm{z}=-14.48, \mathrm{p}=0.00)$ and to zone 6 in comparison with the zones 1 and $5(\mathrm{z}=-14.56, \mathrm{p}=0.00$, and $\mathrm{z}=-2.51, \mathrm{p}=0.01$, respectively). In conclusion men set the ball to the attacking areas of the front court in a hierarchical order. Firstly, they set the ball to position 4, secondly to position 3 and then to position 2 (Figure 1).

\section{Setting zone choices by female setters}

Female setters carried out 2093 setting actions, in total. Of these, $7.3 \%$ were sent to zone $1,28.3 \%$ to zone $2,16 \%$ to zone $3,38.6 \%$ to zone $4,1 \%$ to zone 5 and $8.8 \%$ were sent to zone 6 . The comparison of percentages 
and frequencies showed that women set the ball more frequently to zone 4 in comparison with the zones $1,2,3$, 5 and $6(\mathrm{z}=-7.86, \mathrm{p}=0.00, \mathrm{z}=-4.01 \mathrm{p}=0.00, \mathrm{z}=-7.45 \mathrm{p}=0.00, \mathrm{z}=-2.60, \mathrm{p}=0.009$ and $\mathrm{z}=-12.13, \mathrm{p}=0.00$, respectively). Moreover, women set the ball more frequently to zone 2 in comparison with the zones 1,3 and 6 $(\mathrm{z}=10.18, \mathrm{p}=0.00, \mathrm{z}=4.22, \mathrm{p}=0.00 \mathrm{\kappa} \alpha \mathrm{z}=-14.36, \mathrm{p}=0.00$, respectively), to zone 3 more frequently in comparison with the zones 1 and $6(\mathrm{z}=12.33, \mathrm{p}=0.00$ and $\mathrm{z}=-15.93, \mathrm{p}=0.00)$ and to zone 6 in comparison with the zones 1 and $5 \mathrm{z}=-3.51, \mathrm{p}=0.00$, and $\mathrm{z}=-8.35, \mathrm{p}=0.00$, respectively). In conclusion women set the ball to the attacking areas of the front court in an hierarchical order. Firstly, they set the ball to position 4, secondly to position 2 and then to position 3 (Figure 1).

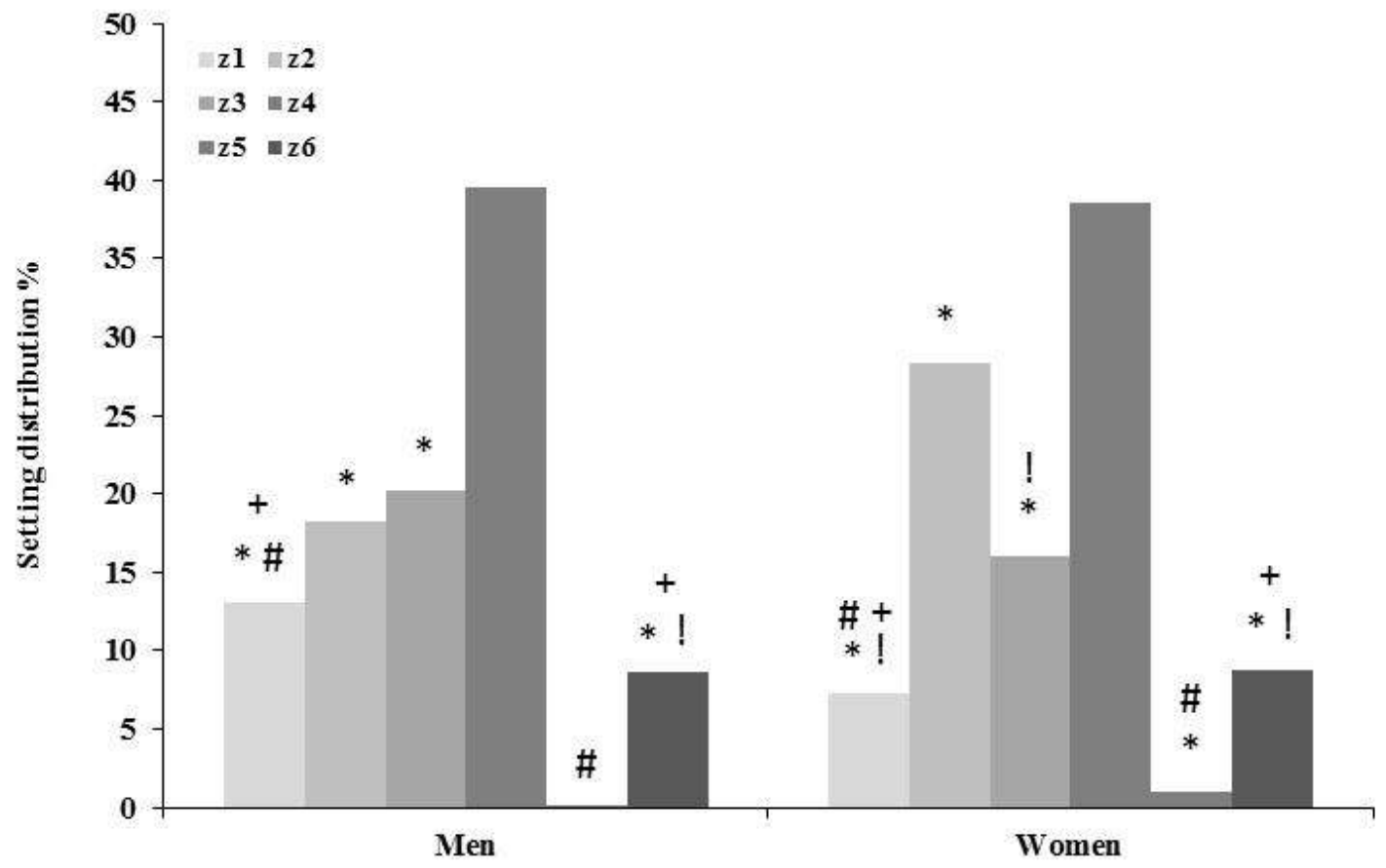

Figure 1. Setting zone distribution percentages of elite male and female setters. ! $\mathrm{p} \leq 0.05$ from setting distribution to zone $2,+\mathrm{p} \leq 0.05$ from setting distribution to zone $3, * \mathrm{p} \leq 0.05$ from setting distribution to zone $4, \# \mathrm{p} \leq 0.05$ from setting distribution to zone 6 .

Comparison and assessment of the setting zone choices by male and female setters

The comparison of percentages and frequencies between genders showed that male setters set the ball to positions 1 and 3 more frequently compared to females $(z=-37.5, p=0.0$ and $z=3.41, p=0.0006$, respectively) while the latter set the ball more frequently to position 2 in comparison with their male counterparts $(z=-7.33$, $\mathrm{p}=0.000)$ (Table 1).

Table 1.Setting zones in relation to gender

\begin{tabular}{|c|c|c|c|c|c|c|c|}
\hline & \multicolumn{6}{|c|}{ Setting zones } & \multirow{2}{*}{$\begin{array}{c}\mathrm{X}^{2} \\
\text { Value } \\
\text { Sig. }\end{array}$} \\
\hline & $\begin{array}{c}1 \\
\%(\mathrm{~N})\end{array}$ & $\begin{array}{c}2 \\
\%(N)\end{array}$ & $\begin{array}{c}3 \\
\%(N) \\
\end{array}$ & $\begin{array}{c}4 \\
\%(N) \\
\end{array}$ & $\begin{array}{c}5 \\
\%(N) \\
\end{array}$ & $\begin{array}{c}6 \\
\%(N) \\
\end{array}$ & \\
\hline Men & $13.1(238)$ & $18.3(332)$ & $20.2(366)$ & $39.5(716)$ & $0.1(1)$ & $8.7(158)$ & 98.600 \\
\hline Women & $7.3(153)$ & $28.3(593)$ & $16(334)$ & $38.6(808)$ & $1(20)$ & $8.8(185)$ & 0.000 \\
\hline $\begin{array}{l}\mathbf{Z} \\
\mathbf{P} \\
\end{array}$ & $\begin{array}{c}-37.5 \\
0.0 \\
\end{array}$ & $\begin{array}{l}-7.33 \\
0.000 \\
\end{array}$ & $\begin{array}{c}3.41 \\
0.0006 \\
\end{array}$ & $\begin{array}{c}0.57 \\
\mathrm{~ns}\end{array}$ & $\begin{array}{c}-11.97 \\
0.0 \\
\end{array}$ & $\begin{array}{c}-0.94 \\
\mathrm{~ns}\end{array}$ & \\
\hline
\end{tabular}

Men: $\mathrm{N}=1811(100 \%)$, Women: $\mathrm{N}=2093(100 \%)$.

Comparison and assessment of the setting zone choices by male and female setters in combination with the organization of the opponent block.

A total of 1804 attacks were carried out by the men hitters. Of these, 3.9\% were performed against no block formation, 27.5\% against single block, $62.7 \%$ against double block and $5.8 \%$ were performed against triple block formation. The great majority of the achieved blocks were carried out against the attacks performed from position 4 (39.6\%). Then most of the achieved blocks were performed in a hierarchical order against the attacks from positions $3,2,1$ and $6(20.1 \%, 18.3 \%, 13.2 \%, 8.8 \%$, respectively). On the other hand female hitters performed a total of 2075 attacks. Of these, $4 \%$ were performed against no block formation, 14.2\% against single block, $75.8 \%$ against double block and $6 \%$ were performed against triple block formation. The great majority of the achieved blocks were carried out against the attacks performed from position 4 (38.7\%). Then most of the 
achieved blocks were performed in a hierarchical order against the attacks from positions 2, 3, 6, 1 and 5 (28.3\%, $15.8 \%, 8.9 \%, 7.4 \%$ and $1 \%$, respectively). Female hitters confronted no block more frequently than males when attacked from zones 1,2 and $4(\mathrm{z}=-12.19, \mathrm{p}=0.0, \mathrm{z}=-3.69, \mathrm{p}=0.0002$ and $\mathrm{z}=-7.04, \mathrm{p}=0.000$, respectively). On the other hand, men confronted no block more frequently in comparison with women when attacked from zones 3 and $6(\mathrm{z}=2.70, \mathrm{p}=0.007$ and $\mathrm{z}=3.14, \mathrm{p}=0.002$, respectively) and a single block when attacked from zones $1,2,3$, 4 and $6(\mathrm{z}=-6.29, \mathrm{p}=0.000, \mathrm{z}=3.30, \mathrm{p}=0.0009, \mathrm{z}=5.56, \mathrm{p}=0.000, \mathrm{z}=-21.95, \mathrm{p}=0.0$ and $\mathrm{z}=4.67, \mathrm{p}=0.000$, respectively). Men faced a double block formation more frequently in comparison to women, when attacked from position $4(\mathrm{z}=-6.33, \mathrm{p}=0.000)$ while the latter faced the same block formation more frequently in comparison to their male counterparts when attacked from positions $2,3,4$ and $6(z=-2.92, p=0.0003, z=-4.59$, $\mathrm{p}=0.000, \mathrm{z}=-6.33, \mathrm{p}=0.000$ and $\mathrm{z}=-2.78, \mathrm{p}=0.005)$. Finally, men hitters confronted triple block formation more frequently in comparison to women, when attacked from positions 1,2 and $4(\mathrm{z}=2.46, \mathrm{p}=0.01, \mathrm{z}=3.47, \mathrm{p}=0.0005$ and $\mathrm{z}=-19.57, \mathrm{p}=0.0$, respectively) while women confronted triple block more frequently in comparison to men when attacked from positions 3 and $6(\mathrm{z}=-13.97, \mathrm{p}=0.0$ and $\mathrm{z}=10.16, \mathrm{p}=0.0)$ (Table 2).

Table 2. Block formation in relation to setting zone

\begin{tabular}{|c|c|c|c|c|c|c|}
\hline \multirow{3}{*}{ Gender } & \multirow{3}{*}{ Setting zones } & \multicolumn{4}{|c|}{ Block formation } & \multirow{3}{*}{$\begin{array}{c}\mathrm{X}^{2} \\
\text { Value } \\
\text { Sig. }\end{array}$} \\
\hline & & No block & One block & Double block & Triple block & \\
\hline & & $\%(N)$ & $\%(N)$ & $\%(N)$ & $\%(N)$ & \\
\hline Men & & $2.9(7)$ & $11.8(28)$ & 81.5 (194) & $3.8(9)$ & 13.743 \\
\hline $\begin{array}{c}\text { Women } \\
\mathrm{Z}\end{array}$ & 1 & $\begin{array}{l}9.2(14) \\
-12.19\end{array}$ & $\begin{array}{c}3.9(6) \\
-6.29\end{array}$ & $\begin{array}{c}84.3(129) \\
-0.71\end{array}$ & $\begin{array}{c}2.6(4) \\
2.46\end{array}$ & 0.003 \\
\hline $\mathbf{P}$ & & 0.0 & 0.000 & ns $\ldots$ & 0.01 & \\
\hline Men & & $1.8(6)$ & $21.2(70)$ & $75.2(248)$ & $1.8(6)$ & 12.817 \\
\hline Women & 2 & $2.9(17)$ & $12.9(76)$ & $83.2(489)$ & $1.0(6)$ & 0.005 \\
\hline $\mathbf{Z}$ & 2 & -3.69 & 3.30 & -2.92 & 3.47 & \\
\hline $\mathbf{P}$ & & 0.0002 & 0.0009 & 0.003 & 0.0005 & \\
\hline Men & & $3.0(11)$ & $60.3(219)$ & $36.4(132)$ & $0.3(1)$ & 42.512 \\
\hline Women & & $2.1(7)$ & $39.1(128)$ & $53.8(176)$ & $4.9(16)$ & 0.000 \\
\hline $\mathbf{Z}$ & 3 & 2,70 & 5.56 & -4.59 & -13.97 & \\
\hline $\mathbf{P}$ & & 0.007 & 0.000 & 0.000 & 0.0 & \\
\hline Men & & $1.4(10)$ & $17.6(126)$ & $70.3(502)$ & $10.6(76)$ & 56.191 \\
\hline Women & 4 & $2.9(23)$ & $7.4(59)$ & $83.9(673)$ & $5.9(47)$ & 0.000 \\
\hline $\mathbf{Z}$ & 4 & -7.04 & -21.95 & -6.33 & -19.57 & \\
\hline $\mathbf{P}$ & & ـ & 0.0 & 0.000 & 0.0 & \\
\hline Men & & $100(1)$ & 0 & 0 & 0 & $4.462^{-}$ \\
\hline Women & & $15.0(3)$ & $10.0(2)$ & $65.0(13)$ & $10.0(2)$ & 0.216 \\
\hline $\mathbf{Z}$ & 5 & -0.14 & - & - & - & \\
\hline P & & ns & - & $-\ldots$ & - & \\
\hline Men & & $22.8(36)$ & $34.2(54)$ & $34.8(55)$ & $8.2(13)$ & 45.996 \\
\hline Women & 6 & 10.3 (19) & $13.0(24)$ & 49.7 (92) & $27.0(50)$ & 0.000 \\
\hline $\mathbf{Z}$ & 6 & 3.14 & 4.67 & -2.78 & 10.16 & \\
\hline $\mathbf{P}$ & & 0.002 & 0.000 & 0.005 & 0.0 & \\
\hline
\end{tabular}

Men: N= 1804 (100\%), Women: N= 2075 (100\%).

\section{Discussion}

The purpose of this study was the comparison of the setting zone choices by male and female elite setters, as well as their resulting impact on the organization of the opponent block. Our results revealed that the distribution strategy of the men setters included all setting zones although zone 4 was the first choice for both genders. However, it was obvious that men preferred the setting to zone 1 compared to women who preferred zone 2. According to Mesquita and Cesar (2007), the opposite player's attacks from zone 1 made by men were more efficient than those made by women in the 2004 Olympics. Women's attacks from zone 1 were more likely to be a back-up solution rather than an actual tactical option. Possibly, this may be partly attributed to the fact that male opposite hitters have the very important task to perform spikes in difficult situations, after imprecise serve receptions and field defence actions, at which they have to confront a compact double or triple block (Araujo, Castro, Marcelino \& Mesquita,2010). In fact, it can be assumed that a critical factor for the win in the set is the spiking efficiency of the opposite hitters in difficult situations (Grantov, Jelaska\&Dragutin, 2018). In addition to this, men are more effective in spiking because of the greater power of their attack in comparison with their female counterparts (Palao et al., 2009). According to Forthomme and Corisier (2005) the spike ball's speed for men, varies between $61.2 \mathrm{~km} / \mathrm{hr}$. and $112.3 \mathrm{~km} / \mathrm{hr}$., while for women the range was lower, averaging between $45.8 \mathrm{~km} / \mathrm{hr}$. and $82.5 \mathrm{~km} / \mathrm{hr}$. These differences may explain the differences in spike performance and have obvious implications for ball speed, execution speed, and possibilities for attack areas (Palao, et al., 2005; Bergeles, et al., 2009). On the other hand, zone 2 seemed to be more preferable by the women setters possibly because of the total offensive actions carried out from both the outside hitters and the middle attackers.

The present study revealed that, overall, men and women formatted mainly single and double block. Moreover, when female hitters attacked from zones 1, 2 and 4, confronted no block more frequently than male. In the first case, the absence of block may be due to the tactical decision of the defending team. Indeed, it seems 
that in female volleyball the back-court attack is not so powerful and the predominance of placed and/or slower attacks (César \& Mesquita, 2006; Costa et al., 2012) may be a good reason for the absence of block. In the second case, a possible reason might be the fast attacking tempo of mainly the female middle attackers when attacking from the position 2. On the other hand, when men attacked from zone 6, faced either no block or a single one, more frequently than women. In addition to this, no block was faced by men more frequently when they attacked from positions 1,2 and 3. The aforementioned may be attributed to the fact that the attacking tempo of both the middle and the outside hitter were very fast. Our results also showed that when men attacked from position 1 faced a triple block formation more frequently in comparison to women. This seems logical, as male opposite hitters have the task to perform spikes in difficult situations, after imprecise serve receptions and field defence actions, at which they have to confront a compact double or triple block (Araujo et al., 2010). However, it is also of particular interest that male hitters confronted a triple block formation more frequently than women even when they attacked from zones 2 and 4 . Possibly, this may be partly explained by the fact that under suboptimal conditions men set the ball mainly to positions 2 and 4 in comparison with women, thus promoting the formation of a triple block. On the other side, when women attacked from positions 2, 3, 4 and 6 faced a double block formation more frequently than men. Possibly, this may be partly explained by the fact that under suboptimal conditions women set the ball mainly to positions 2, 6 and 4 in comparison with men, thus promoting the formation of a double block. For the same reasons women confronted a triple block more frequently than men when attacked from position 6 . In conclusion, the male setters with their tactics mainly released attackers from zones 6 and 3 while women released attackers from zone 2. Also, men confronted organized block when attacking from zones 1 and 4 while women when attacking from zones 2, 3, 4 and 6.

\section{Conclusions}

In conclusion, the setting distribution strategy of both men and women elite setters included all setting zones although zone 4 was the first choice for both genders. However, zones 3 and 2 were the second and third choice for men setters respectively, while zones 2 and 3 were the second and third choice for women setters, respectively. Moreover, the male setters with their tactics mainly released attackers from zones 3 and 6 while women released attackers from zone 2. Also, men confronted organized block when attacking from zones 1 and 4 while women when attacking from zones 2, 3, 4 and 6.

\section{References}

Afonso, J., Mesquita, I., Marcelino, R., Silva, J.A. (2010). Analysis of the setter's tactical action in high performance women's volleyball.Kinesiology, 42 (1), 82-89.

Araújo, R.M., Castro, J., Marcelino, R., Mesquita, I.R. (2010). Relationship between the Opponent Block and the Hitter in Elite Male Volleyball.J Quant Anal Sports, 6(4), 1-12.

Barzouka, K., Nikolaidou, M.E., Malousaris, G. and Bergeles, N. (2006). Performance excellence of male setters and attackers in Complex I and II on volleyball teams in the 2004 Olympic Games. International Journal of Volleyball Research, 9, 19-24.

Bergeles, N., Barzouka, K., Nikolaidou, M. (2009).Performance of male and female setters and attackers on Olympic - level Volleyball teams.International Journal of Performance Analysis of Sport, 9, 141-148.

Bishop P., Cureton, K. and Collins, M. (1987).Sex difference in muscular strength in equally-trained men and women.Ergonomics, 30, 675-687.

Buscà, B., Febrer, J. (2012).Temporal fight between the middle blocker and the setter in high level volleyball. Rev int med cienc act fisdeporte, 12(46), 313-327.

Carter, J.E.L., Powell-Santi L.A. and Rodriguez Alonso C. (1994).Physique and performance of USA volleyball players.In Access to Active Living: Proceedings of the 10th Commonwealth and International Scientific Congress (edited by F.I. Bell and G.H. Van Gyn), pp. 311-316. Victoria, B.C.,Canada.

Castro, J., Souza, A., \& Mesquita, I. (2011). Attack efficacy in volleyball: Elite male teams. Perceptual and Motor Skills, 113(2), 395-408.

César, B., \& Mesquita, I. (2006). Characterization of the opposite player in function of game complex, attack tempo, and attack effectiveness: Research conducted in elite women's volleyball. Brazilian Journal of Physical Education and Sport, 20(1), 59-69.

Costa, G.C., Afonso, J., Brant, E., Mesquita, I. (2012).Differences in game patterns between male and female youth volleyball.Kinesiology, 44(1), 60-66.

FIVB (2018).Official volleyball rules 2017-2020. Retrieved from http://www.fivb.org/EN/RefereeingRules/documents/FIVB-Volleyball_Rules 2017-2020-EN-v06.pdf

Forthomme, B., \&Corisier, J. (2005) Factors correlated with volleyball spike velocity. The American Journal of Sport Medicine, 33, 52-58.

Fröhner, B., \& Zimmermann, B. (1996).Selected aspects of the developments of men's volleyball.The Coach, 4, 14-24.

González-Silva, J., Fernández-Echeverría, C., Claver, F., Conejero, M., \& Moreno, M.P. (2017). How does it affect the setter intervention to the block participation, in high level male volleyball?Journal of Human Sport and Exercise, 12(3proc), S821-S830. 
Grgantov, Z., Jelaska, I., Dragutin, Š. (2018)Intra and interzone differences of attack and counterattack efficiency in elite male volleyball. Journal of Human Kinetics, Ahead of print,DOI: 10.2478/hukin-20180028.

Marcelino, R., Sampaio, J., \& Mesquita, I. (2012). Attack and serve performances according to the match period and quality of opposition in elite volleyball matches. Journal of Strength and Conditioning Research, 26(12), 3385-3391.

Marcelino, R., Afonso, J., Moraes, J., and Mesquita, I. 2014. "Determinants of Attack Players in High-Level Men's Volleyball.'Kinesiology 46 (2), 234-41.

McGown, C. (1974). Probability and team offense.Volleyball Technical Journal, 6, 11-13.

Mesquita, I., \&Graca, A. (2002).Probing the strategic knowledge of an elite volleyball setter: A case study.International Journal of Volleyball Research, 5 (1), 13-17.

Mesquita, I., \& César, B. (2007).Characterisation of the opposite player's attack from the opposition block characteristics. An applied study in the Athens Olympic games in female volleyball.International Journal of Performance Analysis in Sport, 7(2), 13-27.

Moreno, M. P., Moreno, A., Ureña, A., Iglesias, D. \& Del Villar, F. (2008).Application of mentoring through reflection in female setters of the Spanish national volleyball team.A case study.International Journal of Sport Psychology, 39, 59-76.

Palao, J.M., Santos, J.A. and Urena, A.Y. (2004).Effect of team level on skill performance in volleyball.International Journal of Performance Analysis in Sport, 4, 50-60.

Palao, J.M., Santos, J.A., \&Urena, A. (2005).Effect of setter's position on the spike in volleyball.J Hum Movement Stud, 48(1), 25-40.

Palao, J.M., Manzanares, P., Ortega, E. (2009). Techniques used and efficacy of volleyball skills in relation to gender. International Journal of Performance Analysis of Sport, 9, $281 \square 293$.

Palao, J.M., Martínez S. (2013). Use of jump set in relationship to the competition level in male volleyball.SporTK, 1(2), 43-49.

Palao, J.M. \&Ahrabi-Fard, I. (2014). Effect of jump set usage on side-out phase in women's college volleyball. $J$ Sport Human Perf, 2(3), 1-10.

Papadimitriou, K., Pashali, E., Sermaki, I., Mellas, S. and Papas, M. (2004).The effect of the opponents' serve on the offensive actions of Greek setters in volleyball games. International Journal of Performance Analysis in Sport, 4, 23-33.

Reeser, J., \& Bahr, R. (2003).Energy Demands in the Sport of Volleyball.Handbook of Sports Medicine and Science: VOLLEYBALL, US: Blackwell Science: pp. 11-17.

Silva, M., Lacerda, D., João, P.V. (2013). Match analysis of discrimination skills according to the setter attack zone position in high level volleyball.Int J Perf Anal Spor, 13(2), 452-460.

Silva, M., Lacerda, D. and João, P. V. (2014).Game-related volleyball skills that influence victory.Journal of Human Kinetics, 41, 173-179.

Vujmilovic, A., Karalic, T. (2013).Specialization in Volleyball Game-Primary and Secondary Demands from the Setter Position.Sports Science and Health,3(1), 53-63. DOI: 10.7251/SSH1301053V

Wang, Z., Chen, D. (2017). An Optimized Data Mining Algorithm Application in Volleyball Match Technique and Competition Tactics Analysis.BoletínTécnico, 55(17), 782-787.

Zetou, E., Moustakidis, A., Tsigilis, N. and Komninakidou, A. (2006).Playing characteristics of men's Olympic Volleyball teams in complex II.International Journal of Performance Analysis in Sport, 6(1), 172-177.

Zetou E, Moustakidis A, Tsigilis N, Komninakidou A. (2007). Does Effectiveness of skill in complex I predict win in men`s Olympic Volleyball Games? J Quant Anal Sports, 3(4):1-11. 